\title{
A IGREJA UNIVERSAL DO REINO DE DEUS EM CONTRASTE COM A IGREJA MUNDIAL DO PODER DE DEUS: O DISCURSO E O ETHOS DE SEUS LÍDERES
}

\author{
Isabella Lopes de Souza Pinto ${ }^{1}$ \\ Lucas Martins Gama Khalil ${ }^{2}$
}

RESUMO: Este artigo visa analisar a constituição discursiva de Edir Macedo, na Igreja Universal do Reino de Deus (IURD), em comparação com o discurso de Valdemiro Santiago, na Igreja Mundial do Poder de Deus (IMPD). O trabalho se desenvolve com base nos pressupostos teóricos da Análise de Discurso (AD), ancorada especificamente em Dominique Maingueneau, em diálogo com a Argumentação no Discurso, teorizada por Ruth Amossy; visa identificar se as formações discursivas (FDs) que constituem esses discursos se distanciam, a partir da análise do interdiscurso, da intertextualidade, do modo de enunciação (que engendra um ethos para o enunciador), da doxa, da adaptação do enunciador ao seu auditório, da cenografia. Para isso, analisa dois vídeos divulgados nos canais oficiais das duas Igrejas no YouTube e transcreve o momento específico em que os líderes solicitam dízimos e ofertas. A IURD, através de Edir Macedo, representa-se como uma Igreja mais ligada a uma origem bíblica, desenvolvendo uma possível fé "racional"; por outro lado, a IMPD, através de Valdemiro Santiago, entende-se como constituída a partir de uma relação mais estreita com elementos do sobrenatural e com uma fé "emocional".

Palavras-chave: Discurso. Argumentação. Neopentecostalismo. Dízimos.

ABSTRACT: This article aims to analyze the discursive constitution of Edir Macedo, in the Universal Church of the Kingdom of God (IURD), compared to the discourse of Valdemiro Santiago, in the Mundial Church of God's Power (IMPD). The work is developed based on the theoretical assumptions of Discourse Analysis (DA), anchored specifically in Dominique Maingueneau, in dialogue with Argumentation in Discourse, developed by Ruth Amossy; it aims to identify whether the Discursive Formations (DFs) that constitute these discourses differ from each other, based on the analysis of interdiscourse, intertextuality, the mode of enunciation (that engenders an ethos to the enunciator), doxa, adaptation of the enunciator to his audience, and the scenography. To do this, it analyzes two videos posted on the official YouTube channels of the two Churches and transcribes the specific moment when leaders request tithes and offerings. The IURD, through Edir Macedo, represents itself as a Church more connected to a biblical origin, developing a possible "rational" faith; on the other hand, the IMPD, through Valdemiro Santiago, is understood as constituted from a closer relation with elements of the supernatural and with an "emotional" faith.

Keywords: Discourse. Argumentation. Neo-Pentecostalism. Tithes.

\footnotetext{
${ }^{\mathrm{I}}$ Mestranda em Letras pela Universidade Federal de Rondônia - UNIR. E-mail: lopess.isabella@gmail.com.

${ }^{2}$ Doutor em Estudos Linguísticos pela Universidade Federal de Uberlândia - UFU

Docente do Departamento de Letras Vernáculas da Universidade Federal de Rondônia - UNIR
} 


\section{INTRODUÇÃO}

Este artigo visa analisar os discursos produzidos pelos líderes religiosos das igrejas neopentecostais com maior notoriedade social no Brasil, o Bispo Edir Macedo e o Apóstolo Valdemiro Santiago, na Igreja Universal do Reino de Deus (IURD) e na Igreja Mundial do Poder de Deus (IMPD), respectivamente; busca-se identificar, na análise comparativa das duas denominações, os elementos discursivos que as aproximam e que as diferenciam, em especial, no que concerne à instauração de uma cena enunciativa característica. Para isso, o trabalho tem como base teórica a Análise de Discurso (AD) de linha francesa, ancorada especificamente em estudos de Dominique Maingueneau (2008a; 2008b; 2020), em um diálogo com a proposta da Argumentação no Discurso, desenvolvida por Ruth Amossy (2020).

Essa delimitação, que coloca a IURD em relação com a IMPD, realizada em um espaço discursivo, constitui-se como um recorte do campo discursivo religioso a partir das hipóteses lançadas na pesquisa. Como postula Maingueneau (2008a), ao contrapor analiticamente os posicionamentos jansenista e humanista devoto - objeto de sua pesquisa de doutorado -, torna-se necessário, para os propósitos de uma pesquisa, relacionar determinados discursos em um espaço discursivo passível de ser investigado.

É-se então conduzido a isolar, espaços discursivos, isto é, subconjuntos de formações discursivas que o analista, diante de seu propósito, julga relevante pôr em relação. Tais restrições são resultado direto de hipóteses fundadas sobre um conhecimento dos textos e um saber histórico, que serão em seguida confirmados ou infirmados quando a pesquisa progredir. (MAINGUENEAU, 2008a, p. 35)

Em sua obra mais significativa do ponto de vista teórico-metodológico, Gênese dos Discursos, Maingueneau (2008a) relacionou, em um mesmo espaço discursivo, jansenismo e humanismo devoto, posicionamentos divergentes no interior do campo discursivo religioso: o primeiro seria constituído a partir de uma suposta reação ao humanismo devoto, este que ficou enfraquecido simultaneamente à ascensão do jansenismo, na França do século XVII.

Metodologicamente, a análise aqui proposta pretende observar as relações de sentido e a constituição discursiva que se materializam por meio dos elementos linguísticos, enunciativos e argumentativos colocados em cena nos discursos dos líderes religiosos dessas denominações; conforme a proposta da "prática discursiva como prática intersemiótica" (MAINGUENEAU, 2008a), outros elementos semióticos que integram um culto religioso 
também são pertinentes. Observar-se-á, portanto, as relações entre enunciador e enunciatários, a semântica global (que envolve, dentre outros aspectos, a intertextualidade e a interdiscursividade dentro dos sistemas de restrições desses discursos) e o ethos discursivo. Além disso, será importante a observação sobre a doxa compartilhada em um grupo e a adaptação do orador a esse grupo. Dessa análise, pretende-se apontar algumas considerações sobre o modo como as formações discursivas que constituem esses discursos se antagonizam e em que medida convergem em certos pontos.

O corpus selecionado para este trabalho se compõe a partir de recortes de dois vídeos publicados no YouTube, nos canais oficiais das Igrejas ${ }^{3}$. Nos vídeos, foi transcrito o momento específico dentro de dois cultos religiosos, um da IURD e outro da IMPD, em que os líderes solicitam dízimos e ofertas. A opção por analisar esse momento do culto em específico surge justamente do fato de, no neopentecostalismo, a teologia da prosperidade ser um dos principais pilares de sustentação do movimento, e por estamos inseridos em uma sociedade marcada pelo capitalismo, que supervaloriza os bens e as riquezas materiais. $\mathrm{Na}$ teologia da prosperidade, há a crença de que a pessoa só não é bem-sucedida na vida se não tiver fé o suficiente, colocando em destaque o homem, representado como dominante na relação estabelecida com Deus. A teologia da prosperidade sustenta que o plano de Deus para o homem na Terra é fazê-lo feliz, abençoado, saudável, próspero. No entendimento de Rossi (2015), trata-se de um produto do capitalismo:

\footnotetext{
Buscando justificativa em textos isolados da Bíblia, a teologia da prosperidade não passa de produto do capitalismo e da psicologia do sucesso que domina a maioria das nações industrializadas e atinge também as nações pobres. É uma reflexão que, feita não à luz da Bíblia, mas da procura de privilégios, estimula a insensibilidade diante da injustiça presente no mundo. ${ }^{4}$
}

Temos, então, posicionamentos pertencentes ao campo discursivo religioso, este que é considerado por Maingueneau (2008b) como "constituinte” (pela representação imaginária de uma relação direta com a fonte legitimadora, Deus), e de visada argumentativa, na concepção de Ruth Amossy (2020). Imbricando essas duas perspectivas teóricas, corroboramos com a posição de Amossy (2011, p. 129) de que não há como se separar a

\footnotetext{
3 Disponíveis em https://www.youtube.com/user/TvUniversalorg https://www.youtube.com/user/IMPDRJ. Acesso em or de agosto de 2021.

4 Disponível em: https://www.vidapastoral.com.br/artigos/temas-teologicos/a-biblia-reinterpretada-pelateologia-da-prosperidade/. Acesso em or de agosto de 202I.
} 
argumentação do discurso: "Na medida em que a Análise de Discurso (AD) espera descrever o funcionamento do discurso em situação, ela não pode negligenciar a sua dimensão argumentativa".

Deve-se esclarecer que este trabalho apresenta apenas um recorte de uma pesquisa mais ampla, na qual têm sido analisados outros vídeos das duas denominações, sempre no momento em que se solicitam dízimos e ofertas. Dessa forma, as limitações espaciais de um artigo fazem com que se opte por apresentar duas análises, com o objetivo de que elas possam ser ilustrativas de um funcionamento discursivo mais amplo, analisado no decorrer da pesquisa.

\section{ANÁLISE DO DISCURSO E ARGUMENTAÇÃO: UM ENCONTRO}

No quadro da Análise de Discurso francesa, inserem-se os estudos empreendidos por Dominique Maingueneau, a partir do final dos anos 1970 e, com mais relevância, em meados dos anos 1980. O teórico propõe o tratamento do discurso a partir de uma semântica global, isto é, são destacadas como pertinentes todas as dimensões do discurso. Também chamadas de planos (vocabulário, intertextualidade, tema, dêixis, estatuto do enunciador e do destinatário, modo de enunciação etc.), essas dimensões integram-se e fazem funcionar o discurso socialmente. Por isso, segundo esse autor, não se deve privilegiar análises, estritamente, lexicológicas, focadas na "escolha” das palavras, por exemplo. O discurso deve, então, ser tomado e analisado a partir da relação entre os planos, como um todo global.

A partir de agora, serão desenvolvidas explanações sobre alguns desses planos integrantes da semântica global (citados anteriormente) e sobre outros elementos da $A D$, como as noções de primado do interdiscurso, formação discursiva e ethos discursivo, pois são pressupostos teóricos que se fazem presentes na análise dos vídeos transcritos. Além disso, abordar-se-á brevemente a noção de doxa, integrada aos estudos do discurso, e a adaptação do orador aos seus auditórios, a partir dos desdobramentos teóricos desenvolvidos por Ruth Amossy.

A especificidade da noção de interdiscurso postulada por Dominique Maingueneau está na focalização da relação de não separação entre o Mesmo do discurso e seu Outro (formação discursiva representada, sob a forma de simulacro, como concorrente em um campo discursivo); por isso, o "primado do interdiscurso". Nessa perspectiva, o interdiscurso passa a 
ser entendido como um espaço de regularidade em que o discurso encontra apoio para se constituir. Além disso, do ponto de vista metodológico (diferenciando-se de Michel Pêcheux, fundador da $\mathrm{AD}$ francesa), há a substituição do interdiscurso por uma tríade: universo discursivo, campo discursivo e espaço discursivo.

Pensar em universo discursivo é, a princípio, muito abrangente, pois se encontram nele todas as formações discursivas (FDs) existentes em uma conjuntura dada. Apesar de abrangente, ele é considerado finito. Por ser pouco específico, não é muito útil ao analista. É no interior do universo que são encontrados os campos discursivos, mais suscetíveis de serem estudados.

No campo discursivo, encontra-se um conjunto de formações discursivas que buscam preencher a mesma função social; como exemplos, podem ser citados o campo religioso, literário, político, entre outros. As concorrências que podem ocorrer no interior de um campo discursivo incluem "tanto o confronto aberto quanto a aliança, a neutralidade aparente etc... entre discursos que possuem a mesma função social e divergem sobre o modo pelo qual ela deve ser preenchida" (MAINGUENEAU, 2008a, p. 34).

O espaço discursivo, por sua vez, é uma delimitação dentro do campo discursivo; é um subconjunto de formações discursivas, e selecioná-lo cabe ao analista, não estando, portanto, o espaço discursivo posto a priori. A constituição do espaço discursivo surge a partir de hipóteses do analista, formuladas a partir de seu conhecimento dos textos, em relação com as conjunturas históricas que lhe fornecem condições de enunciabilidade.

A relação que um discurso estabelece com seu Outro não precisa ser localizável em forma de intertexto; essa relação existe ainda mais pela ausência de marcação (interdito) do que pela presença. Compreende-se, a partir de Maingueneau (2008a), que os enunciados apresentam um direito e um avesso inseparáveis. E caberia ao analista o duplo papel de analisar a formação discursiva à qual o discurso remete (direito) e qual o Outro que ele rejeita (avesso), ou seja, quais são as outras FDs às quais aquele discurso faz referência para negá-las.

Em Gênese dos Discursos, Maingueneau não faz uma clara menção ao conceito de ethos, mas pode-se compreender um embrião dessa noção no plano da semântica global denominado "modo de enunciação". O modo de enunciação refere-se a uma maneira de dizer que se configura como legítima em dada formação discursiva. Maingueneau, ao propor a análise do ethos dentro do quadro teórico da Análise de Discurso, apresenta a ideia de vocalidade (ou 
tom) que abrange os textos orais e escritos. Essa vocalidade "permite relacioná-lo a uma fonte enunciativa, por meio de um tom que indica quem o disse" (MAINGUENEAU, 2016, p. 72). Assim, o tom está relacionado ao corpo do enunciador (não ao corpo do indivíduo empírico), que toma o papel de fiador no discurso, configurando-se a partir de indícios materializados no texto, que "por meio de seu 'tom', atesta o que é dito” (MAINGUENEAU, 2008b, p. 64). Dessa forma, o fiador se constitui a partir de um caráter e de uma corporalidade. "O 'caráter' corresponde a um feixe de traços psicológicos. Já a 'corporalidade' é associada a uma compleição corporal, mas também a uma forma de vestir-se e de mover-se no espaço social.” (MAINGUENEAU, 2oi6, p. 72).

A noção de incorporação, mencionada acima, diz respeito à forma como o destinatário se apropria do ethos quando vai interpretá-lo. Assim, no entendimento de Maingueneau, o ato de enunciação dá corpo ao fiador, que é o sujeito que se legitima no discurso, e o destinatário "assimila um conjunto de esquemas que correspondem a uma maneira específica de relacionar-se com o mundo habitando seu próprio corpo" (MAINGUENEAU, 2008b, p. 65). Por último, possibilita-se a constituição de um “corpo" da comunidade imaginária dos que aderem ao discurso. Ou seja, ao enunciar, o orador incorpora (dá-se um corpo) através do discurso e faz haver uma correspondência com outros sujeitos (filiados à mesma FD), através de uma série de esquemas "que definem uma forma concreta, socialmente caracterizável, de habitar o mundo, de entrar em relação com os outros" (MAINGUENEAU, 2008a, p. 93).

A análise argumentativa desenvolvida por Amossy (2011; 2020) está embasada em teorias retóricas, pragmáticas e lógicas e opta por ser uma abordagem ao mesmo tempo: linguageira, pois é nas trocas verbais que ela se constitui; comunicacional, pois visa a um auditório e está em uma relação de interlocução; dialógica, em oposição à dialogal, pois nem sempre se constitui de diálogo efetivo; genérica, levantando a importância dos gêneros do discurso; figural, recorrendo aos efeitos de estilo; textual, sobre a importância da construção de um texto propriamente dito, composto de enunciados que formam um todo.

É parte fundamental na análise argumentativa a consideração sobre o auditório, pois ele é capaz de modificar a condução da argumentação, uma vez que o orador se orienta pelo seu público. O caminhamento da argumentação poderá ser diferente se o público está presente e é participativo, ou se ele não tem direito de resposta, por exemplo. 
No quadro da análise argumentativa, é preciso destacar que a natureza e o estatuto do auditório modificam profundamente a dinâmica da argumentação. Suas modalidades são diferentes se o público ao qual se dirige não tem direito de resposta ou, ao contrário, se for a um interlocutor singular que se mostra parceiro ativo da troca. (AMOSSY, 2020, p. 54).

Dessa maneira, pode-se considerar a existência de diversos auditórios: presente + loquente (troca verbal cotidiana), presente + não loquente (a conferência magistral), ausente + loquente (a comunicação telefônica), ausente + não loquente (a maior parte das comunicações escritas)ร. Por isso, é importante não somente saber qual o auditório está se relacionando com o orador, mas também de que forma a imagem que o orador construiu dele estará posta na materialidade dos enunciados.

Todo discurso é a palavra sendo utilizada em situações concretas de interação, em que a presença do público (um tu/você enunciativamente estabelecido) é fundamental e muitas vezes decisiva para o eu na construção de enunciados persuasivos, assim, as influências são recíprocas; esse funcionamento se complementa à importância da compreensão sobre o interdiscurso e sobre o ethos, conforme já apresentado.

Não há discurso sem enunciação (o discurso é o efeito da utilização da linguagem em situação), sem dialogismo (a palavra é sempre, como diz Bakhtin, uma reação à palavra do outro), sem apresentação de si (toda fala constrói uma imagem verbal do locutor), sem o que poderia chamar 'argumentatividade' ou orientação, mais ou menos marcada do enunciado, que convida o outro a compartilhar modos de pensar, de ver, de sentir... Nesse sentido, o estudo da argumentação e do modo como ela se alia aos outros componentes na espessura dos textos é parte integrante da análise do discurso (AMOSSY, 2020, p. 12).

A Nova Retórica de Chaïm Perelman, um dos sustentáculos da teoria da argumentação de Amossy, traz à tona a importância de o orador levar em consideração o seu auditório e a doxa no processo de argumentação. A noção de doxa, inserida nos estudos da Argumentação no Discurso por Amossy a partir de uma análise desse termo na antiguidade clássica, coloca em questão a importância da opinião comum no processo de persuasão discursiva. Auditório é um termo retórico que se refere a todo alocutário, e que Perelman (apud AMOSSY, 2020, p. 52) descreve como "o conjunto daqueles que o orador quer influenciar com sua argumentação",

\footnotetext{
${ }^{5}$ Para essa classificação, Amossy (2020) recorre à pesquisadora Catherine Kerbrat-Orecchioni.
} 
que é, no funcionamento discursivo, uma construção daquele que enuncia, ainda que o público se faça presente diante do enunciador.

A doxa se materializa na linguagem, pois ela é materializada a partir de palavras e não se deve falar em apenas uma, pois podem ser várias em diferentes conjunturas históricas. Por isso, muitas vezes, cabe ao analista levar em consideração o arquivo em que funciona o interdiscurso para entender como um texto se alinha a uma posição ideológica. Conforme Amossy (2020, p. I16), "se o conhecimento do que se pensava e se dizia em uma época passada é necessário à boa compreensão de um discurso argumentativo, ele também é desejável quando se trata de um texto contemporâneo concernente a uma cultura diferente”.

Sendo o discurso religioso analisado neste artigo, considera-se importante apresentar a noção de discursos constituintes, mesmo que brevemente. Maingueneau (2008b), ao propor uma discussão sobre eles, disserta que alguns são caracterizados como tal por se colocarem como zonas de fala que não admitem outra autoridade além de sua própria, não reconhecendo outros discursos acima deles e alegando não sofrer influências de outros discursos, sobretudo, por estar representado imaginariamente em relação direta com uma fonte legitimadora (no caso, Deus). No entanto, apesar de se colocarem dessa forma, os discursos constituintes entram em relação, sim, com discursos não constituintes e constituintes, “[...] mas faz parte da natureza dos discursos constituintes negar essa interação ou pretender submetê-la a seus princípios" (MAINGUENEAU, 2008b, p. 37).

\section{ANÁLISES}

Nesta seção, serão transcritos, e posteriormente analisados, enunciados proferidos por Edir Macedo e Valdemiro Santiago em cultos. Os vídeos dos quais os trechos foram retirados estão disponíveis na plataforma YouTube, no canal da Igreja Universal do Reino de Deus e no canal da Igreja Mundial do Poder de Deus, respectivamente.

\section{"A escola de fé inteligente" 6 - 25/II/2020 (Publicado em 25/II/2020)}

A Escola de fé inteligente é, segundo a própria IURD, a reunião dedicada a todos aqueles que buscam a salvação eterna; ela acontece às quartas-feiras. $\mathrm{O}$ vídeo está disponível

\footnotetext{
${ }^{6}$ https://www.youtube.com/watch?v=-ijiBhdWeRQ\&t=4875s. Acesso em ro de dezembro de 2020.
} 
no canal oficial da Igreja Universal, tem ih 52min 32 de duração, consta com 51 mil visualizações, 3,7 mil "likes" e 79 “dislikes". O vídeo foi publicado no dia 25 de novembro de 2020.

Ih I3min 36s a Ih I8min 52s: [Edir Macedo] - Você que trouxe seu voto, você que trouxe a sua oferta, enfim...traga à frente ou então aí nos corredores, coloque dentro do gazofilácio. Fique à vontade, por favor. Quem tem fé pra dar, tem fé pra receber. Quem não tem fé para dar, tem para receber? É lógico, claro que não. Então, só depende de você. A oferta de fé, a oferta de fé. Não pode ser a oferta pra agradar o bispo, a igreja não, é para Deus. É para o altíssimo Deus, que vê a sua situação. Mesmo você que está aí, com a sua situação crítica economicamente, que que você tem para dar? Duas moedas? Não sei... seja lá o que você tiver, minha amiga, faça uma prova com Deus aí agora. "Oh, Deus, eu vim aqui com o dinheiro da passagem. Se eu der o dinheiro da passagem, eu não tenho como voltar para casa. Meu Deus, que que o senhor vai fazer? Eu vou fazer uma prova contigo, eu vou dar esse dinheiro, essas moedinhas e eu quero ver que que o senhor vai fazer”. Faça um teste com Ele, Ele disse: "provai e vede". E ele vai providenciar aquilo que você precisa com certeza, mas você tem que provar. Graças a Deus. Se você quiser adquirir a Bíblia.... essa bíblia nossa, ela tem uma vantagem, ela tem as nossas, ééé...nossos comentários de fé. Nós explicamos aquilo que nós recebemos. Nós levamos as pessoas a uma atitude de pensar, de raciocinar, nós não levamos as pessoas a uma fé irracional, uma fé emotiva. Nós levamos as pessoas a pensar, por isso nós temos aqui, embaixo dos textos sagrados, comentários meus, pessoais, pra que você possa ter uma ideia daquele assunto que você está lendo. Amém, pessoal? Então, você só encontra nessa bíblia aqui "fiel". E eu vou ser honesto com você, presta atenção: essa bíblia aqui a linguagem dela é mais difícil do que as outras bíblias. Ela é uma bíblia com uma linguagem assim... às vezes, eu tenho que ir no dicionário pra entender a palavra. Mas tem uma coisa: é que eu não quero que você fundamente a sua fé numa linguagem, digamos assim, como se diz, uma linguagem democrática, uma linguagem fácil, porque dentro da linguagem fácil, você vai encontrar uma linguagem que nada tem a ver com os originais. Essa bíblia aqui, ela é complicadinha por causa dela ter os seus textos originais, os mais fiéis originais. Entende o que estou falando, sim ou não? Você pode pegar uma bíblia e você vai ver muitos textos que não condizem com a realidade. Quando Deus chama Abraão, quando Deus fala com Abraão, Ele diz assim: “Eu sou o Teu escudo”, que 
quer dizer protetor “e o Teu grandíssimo galardão.” Galardão já é grande, já é enorme, mas quando Deus fala grandíssimo, Ele está super, hiper, tentando mostrar a grandeza que Ele tinha para Abraão. Se você ler nas bíblias normais, você vai ler: "Eu sou Teu escudo, Teu galardão será sobremodo grande” mais nada. Sobremodo grande, você não tem a ideia, mas quando Deus fala "grandíssimo", Ele está supervalorizando o galardão que Ele promete, amém? Não é simplesmente "Teu o galardão será grande”. Se você quiser a bíblia, rapidinho, custa 150,00 reais, por favor, pode vir à frente.

O título da pregação "Escola de fé inteligente” já sugere uma recorrência contrastante a um Outro discursivo que se estabeleceria como constituído a partir de uma fé não inteligente (ou emocional, ou irracional), a qual não necessariamente ficará marcada no texto em forma de "fé inteligente $\mathrm{x}$ fé emocional”, pois “não há necessidade de dizer, a cada, enunciação, que ele não admite esse Outro” (MAINGUENEAU, 2008a, p. 37). Esse Outro que constrói enunciados supostamente com "fé não racional” seria o avesso do discurso da Universal, constituído na rejeição da semântica de seu Outro. Esse contraste com o Outro ficará visível também no trecho mais à frente, quando uma Bíblia é comercializada; de forma mais enfática, o enunciador se opõe a uma fé "emotiva” no seguinte excerto:

Ih 15 min 27 s a Ih 17 min I4s: [Edir Macedo] - Nós levamos as pessoas a uma atitude de pensar, de raciocinar, nós não levamos as pessoas a uma fé irracional, uma fé emotiva. Nós levamos as pessoas a pensar, por isso nós temos aqui, embaixo dos textos sagrados, comentários meus, pessoais, pra que você possa ter uma ideia daquele assunto que você está lendo. Amém, pessoal? Então, você só encontra nessa bíblia aqui "fiel". E eu vou ser honesto com você, presta atenção: essa bíblia aqui a linguagem dela é mais difícil do que as outras bíblias. Ela é uma bíblia com uma linguagem assim... às vezes, eu tenho que ir no dicionário pra entender a palavra. Mas tem uma coisa: é que eu não quero que você fundamente a sua fé numa linguagem, digamos assim, como se diz, uma linguagem democrática, uma linguagem fácil, porque dentro da linguagem fácil, você vai encontrar uma linguagem que nada tem a ver com os originais. Essa bíblia aqui, ela é complicadinha por causa dela ter os seus textos originais, os mais fiéis originais (grifos nosso).

O título também se faz pertinente para compreender a emergência de um tom professoral na fala de Edir Macedo. Há uma relação interdiscursiva com a cena enunciativa proveniente de ambientes escolares, que funciona a partir de duas posições bem definidas em uma sala de aula: aquele/aquela que detém o conhecimento (professor/professora) e aquele/aquela que deve assimilar o conhecimento (aluno/aluna) reconhecendo a autoridade do docente. Estabelece-se uma correspondência entre o que o aluno faz ao ir à escola e o que 
as pessoas fazem ao ir a essa reunião da IURD. Apesar de o discurso religioso ser entendido como constituinte e, por isso, não admitir, ilusoriamente, "influências" de outros discursos (constituintes ou não), entendemos que o discurso religioso é atravessado, nesse caso, pelo escolar.

O trecho citado anteriormente contribui também para a configuração do ethos de líder inteligente, erudito, intelectual. Nota-se que o enunciador fala: "comentários meus, pessoais" [com bastante ênfase], ou seja, são os comentários pessoais do Bispo, a partir de uma figura da autoridade quanto ao conhecimento que detém, que conferem a intelectualidade, a inteligência de uma fé. $O$ auditório é colocado, assim, na posição de insciente, que não tem, pelo menos a princípio, conhecimento ou condições de (sozinho) refletir, raciocinar, pensar sobre o material textual que está lendo.

Há, nos enunciados do Bispo, uma menção a uma "linguagem mais difícil” por ser, supostamente, mais relacionada, em sua essência, aos textos bíblicos originais; há uma oposição estabelecida entre linguagem difícil e linguagem fácil, linguagem original e linguagem democrática (no sentido de "acessível demais"). Edir Macedo coloca a IURD como uma igreja mais ligada à tradição cristã, a uma possível origem, fazendo relações intertextuais com os textos sagrados antigos (em que as compreensões seriam supostamente mais próximas daquilo que Deus queria falar); tenta, então, distanciar-se de uma linguagem mais "democrática", mais fácil, uma linguagem que, aparentemente, no seu entendimento, estaria mais distante de Cristo. Desse modo, produz-se, na relação indissociável entre um "direito" e um "avesso", o simulacro de seu Outro, que teria uma linguagem mais fácil, mais democrática, no entanto, mais distante dos textos originais, distante de uma suposta verdade, que só seria possível de ser veiculada através de Edir Macedo e de sua Igreja. Podese estabelecer um diálogo entre esta passagem e o vídeo analisado mais à frente, no qual Valdemiro Santiago coloca discursivamente a IMPD como uma instituição abrangente, que está em vários lugares, democrática. Há, então, nessa relação, rejeições constitutivas da identidade de cada FD: a IURD rejeita a IMPD (e o inverso também acontece); ambas não aceitam o seu Outro.

“Só depende de você" é um enunciado recorrente em discursos que se fundamentam na teologia da prosperidade, pois nela acredita-se que o tudo aquilo que se recebe (ou não) de Deus se restringe ao fato de o fiel ter fé (acreditar) ou não. O fiel se torna um ser ativo e 
Deus passivo na relação homem-Deus. Isso dialoga com a doxa desse grupo: o orador compreende que seu auditório quer estar no poder. Quem tem muita fé, recebe muito, quem tem pouca fé, recebe pouco, a medida seria a fé: “Quem tem fé para dar, tem fé pra receber. Quem não tem fé para dar, tem para receber? É lógico, claro que não”. Assim, emergem formulações no sentido de "colocar Deus em prova", como em: "faça uma prova com Deus aí agora”. O enunciador incita o público a dar aquilo que tem disponível naquele instante a fim de que Deus prove que "honra" quem tem fé nEle; se o resultado não acontecer, significa que o fiel não teve fé o suficiente. Dessa forma, é mais fácil alcançar o convencimento de seu público, pois o ônus dificilmente cairá em cima do(s) pastor(es), que sairiam ilesos como intermediários.

A relação com o auditório emerge, enunciativamente, através do uso do pronome de tratamento "você", também através do vocativo "minha amiga", que sugere uma aproximação entre enunciador e enunciatários e faz parecer, em alguns momentos, que o sermão está sendo direcionado a mulheres, talvez porque ele esteja vendo mais pessoas do sexo feminino do que masculino. Ademais, apresenta-se uma oscilação entre o tom professoral (comentado no início desta análise) e o tom de um amigo.

No próximo tópico, há a transcrição de um vídeo pertencente à Igreja Mundial do Poder de Deus, seguida da análise.

"A tentação de Jesus"7 - 10/o5/2015 (Publicado em II/o5/2015)

O vídeo intitulado “A tentação de Jesus - Mateus 4" tem duração total de Ih 53 min Ios e está disponível no canal da Igreja Mundial do Poder de Deus do Rio de Janeiro (IMPDRJ), foi gravado no dia ro de maio de 2015 e publicado no dia il de maio de 2015. Ele tem II4 mil visualizações, 2 mil "likes” e I69 “dislikes”, há II9 comentários.

Ih 4omin a Ih 4omin o6s: [Valdemiro Santiago] - Igreja, vamos honrar a obra do Senhor agora? Vamos apresentar os dízimos, ofertas.

Ih $40 \mathrm{~min}$ 07s a ih $40 \mathrm{~min} 54 \mathrm{~s}[\ldots]$

Ih 4omin 55s a rh 43min ors [Valdemiro Santiago] - Igreja, nós estamos reformando a... construindo, na verdade, a nossa sede ali. É a segunda cidade mundial, no caso, é a

\footnotetext{
${ }^{7}$ https://www.youtube.com/watch?v=xbl-Sx6CelU. Acesso em 3I de julho 202I.
} 
principal, mas a segunda porque lá em Santo Amaro já tá funcionando, né. Você tem visto, e nós temos o programa na TV para sustentar e milhares de funcionários. São 5 mil igrejas no Brasil e é a Igreja que mais cresce no mundo, você sabia? Quem viu imagens, no Japão, o Apóstolo batizando? Nesses dias, estive no Japão, nós tivemos batizando o povo lá, né? No Japão. Quem viu a gente batizando os índios? Você viu, filha? Não viu não? Cê tem certeza? Gente, apresenta agora o seu dízimo. Nesse mês de maio, nós estamos chamando o povo pra devolver em dobro. Viu o angolano testemunhando? Quem tem sido abençoado nesta obra? Levanta a mão. Glória a Deus! Olha, maravilha, gente. Você viu quanto tempo nas drogas aquela família lá que cortou a artéria, né? O pai era drogado há muitos anos; hoje é uma família abençoada. A obra de Deus é assim, então apresenta agora, e você que é um dizimista fiel, de tudo que o Senhor lhe der, devolva o dízimo. Dízimo é io é ro os Io\%, que você vai dar é do seu, dá pra Deus, pra obra de Deus. [Valdemiro sorri e fala] A bebezinha. Io\% é da obra de Deus e io é $1 / 5$ de tudo que Deus lhe der esse mês. Ih $43 \min$ o2s a ih $43 \min 34 \mathrm{~s}[\ldots]$

Ih 43min $35 \mathrm{~s}$ a th $48 \mathrm{~min} 34 \mathrm{~s}$ [Valdemiro Santiago] - Eu queria que você apresentasse a Deus uma oferta deste mês. Na verdade, o dízimo em dobro, né? Como ensinam no Gênesis capítulo 5o, quando José lá no Egito determinou que $1 / 5$ fosse separado pra obra. O dízimo é io, é o que você devolve todo mês. Somente neste mês de maio, estamos convocando a multidão pra fazer essa prova com Deus. Você não tem obrigação não, é para você que acredita e conhece o valor desta obra e como funciona o poder de Deus nessa obra. Amém, gente!? E os que querem o saquitel "sê tu uma benção", liga no o(xx)II... Liga agora.

A instauração de determinada relação com o auditório pelo enunciador está presente no texto e é observada a partir do uso recorrente do pronome pessoal (nós), do pronome de tratamento (você) e do substantivo (povo). Por ser uma análise qualitativa, não quantitativa, contar meramente a quantidade de vezes em que o pronome aparece não parece ser muito viável do ponto de vista da Análise de Discurso; porém, essas recorrências são, em certa medida, importantes para compreender algumas regularidades enunciativas. Primeiramente, o Apóstolo Valdemiro Santiago utiliza o pronome pessoal do caso reto na primeira pessoal do plural, nós, e seu respectivo pronome possessivo “nossa", momento em que ele se inclui e inclui todos os ouvintes da pregação no discurso. Nesse momento de inclusão, em que ele se coloca como parte integrante do público para o qual apela, o pastor 
desenvolve um argumento sobre a necessidade de sustentar uma instituição tão grande como a IMPD, e que esse papel seria de todos. Quem seriam todos? Em se tratando de públicos distintos, temos o público presente e virtual, pois os vídeos publicados na plataforma YouTube podem chegar a qualquer pessoa que tenha acesso à internet. Então, todas as pessoas alcançadas seriam o "nós" de seu discurso, e, por conseguinte, participantes e “proprietárias” da sede da IMPD, pelo menos é o que o discurso estabelece, aparentemente, nesse primeiro trecho. No entanto, logo após, o Apóstolo fala: "Você tem visto, e nós temos o programa na TV [...]”. Percebe-se, nesse outro trecho, que ele distingue quem seria o "nós", passando a ser uma inclusão parcial na qual não estão inseridos os auditórios (auditório sentado nas cadeiras e auditório virtual); o "nós” passa a ser um grupo seleto no qual o Apóstolo está inserido.

Ainda sobre o uso dos pronomes pessoais, em certo momento, Santiago fala: "Eu queria que você apresentasse a Deus uma oferta desse mês”. Percebe-se que ele não institui uma voz divina, uma vez que ele fala para o público apresentar a Deus e não a ele ou à igreja, mas ele se coloca na intermediação (semelhantemente a um sacerdote). $\mathrm{O}$ apresentar a Deus pode soar, a princípio, vago, pois: o que seria apresentar a Deus? O preenchimento dessa lacuna acontece através do sentido que, de forma tácita, o enunciatário estabelece ideologicamente: o público inserido nessa FD compreende o que é o dízimo e qual o papel da Igreja. Também se produz o sentido, através do uso do pronome pessoal de primeira pessoa do singular (eu), de que o que está sendo proposto é uma vontade pessoal, apesar de nos trechos seguintes haver a tentativa de legitimação através da retomada de versículos bíblicos. Há a retomada interdiscursiva daquilo que costuma aparecer através de intertexto, mas o texto não é posto na tela (ou lido). Valdemiro fala: "Como ensinam no Gênesis capítulo 5o, quando José lá no Egito determinou que I/5 fosse separado pra obra”. Porém não aparece a citação tal como está escrita na Bíblia (nem a leitura), o que há é uma espécie de citação indireta. Podemos relacionar essa passagem, na qual ele solicita uma espécie de dízimo em dobro, a uma possível fé "irracional” (significaria "dobrar a aposta" a partir da vontade do pastor), na tradução de Edir Macedo; ou "emocional”, atributo que, diferentemente do pejorativo "irracional”, é reivindicado no discurso da IMPD.

O deslizamento dos sentidos do enunciado é sutil; Valdemiro Santiago começa falando sobre estar em todos os lugares do mundo, algo que parece remeter à onipresença 
divina e a ser, como efeito, uma Igreja mais democrática, e segue para a solicitação de dízimos e ofertas numa linha contínua (não há pausas ou interrupções). Em uma passagem, ele fala: “Gente, apresenta agora o seu dízimo. Nesse mês de maio, nós estamos chamando o povo para devolver em dobro." Quem é esse nós a que o enunciado faz referência? Não parece que o público (presente ou ausente) esteja incluído. Quem é o povo que deve devolver em dobro? Não parece que o próprio Apóstolo esteja incluído. A palavra “devolver” deve ser observada com cautela. Por qual motivo é utilizada esta palavra e não outra em seu lugar? Como Maingueneau (2008a) nos lembra, não há um vocabulário pertencente a um ou outro discurso, mas há uma exploração semântica e não outra. Quando Valdemiro enuncia “devolver", ele está deixando de falar outras tantas palavras possíveis. Esse item lexical estabelece a ideia de uma relação de dívida, afinal, só se devolve algo que é do outro, que foi pego emprestado, por exemplo. O sentido que parece ser estabelecido entre enunciador e enunciatário coloca Deus na posição de responsável por todas as conquistas materiais dos fiéis e, por isso, o fiel tem que Lhe devolver a décima parte, pois Deus lhe fez algo (ou um favor). Porém, a devolução ou é feita através de um sacerdote e não diretamente a Deus (primeira suposição); ou ele (Valdemiro) se põe, de certa forma, na posição de Deus e estabelece uma relação de "dar a Deus é equivalente a dar a Valdemiro, ou à igreja” (segunda suposição). Assim como no vídeo da IURD, há o constante "colocar Deus em prova", construção típica da teologia da prosperidade: "Estamos convocando a multidão pra fazer essa prova com Deus”.

No trecho final da transcrição, Valdemiro enuncia: "Você não tem obrigação não, é para você que acredita e conhece o valor desta obra, e como funciona o poder de Deus nessa obra. Amém, gente!?”. Amossy (2020) disserta sobre a importância do conhecimento sobre a doxa que circula em um público, ainda que proceda de um processo de estereotipagem (pois a doxa está relacionada a estereótipos). Deve-se salientar que o público é bastante distinto, as pessoas são diferentes elas em relação às outras, mas também elas em relação a elas mesmas (pensando-se nos vários papéis sociais que uma pessoa pode exercer). Porém, é preciso que o orador se alicerce em um denominador comum para se comunicar com um auditório tão diversificado e impreciso (uma vez que através do YouTube fica difícil determinar, de modo absoluto, quem são os ouvintes desse discurso). O denominador comum parece ser que aquele/aquela que quer ser seguidor/seguidora de Cristo fará tudo 
que corresponde a um suposto perfil de "verdadeiro" seguidor. Então, há um movimento persuasivo do sujeito no momento em que o Apóstolo fala que o ato de pagar o dízimo é só para quem acredita e para quem conhece o poder de Deus, posto que ninguém que se predispõe a seguir a Cristo gostará de ser chamado de incrédulo ou não conhecedor do poder de Deus.

Enquanto o Apóstolo realiza a pregação, aparece na tela, em forma de legenda, a conta para os internautas fazerem depósitos ou transferências. Essa é uma consideração importante, pois coloca em cena as novas tecnologias introduzidas nas igrejas e as edições dos vídeos (pois a legenda só aparece nos vídeos, havendo, portanto, edição). Essa aparição é direcionada apenas para o público virtual (internautas), o que pode acarretar em relações de sentido diferentes das existentes na presencialidade da igreja.

Valdemiro faz uso de uma linguagem simples na interação com o auditório. A pregação é permeada por interrupções nas quais ele dialoga com uma ou outra pessoa do público, com pastores, fala coisas do cotidiano e continua o sermão, como se observa nesta passagem: "Quem viu a gente batizando os índios? Você viu, filha? Não viu não? Cê tem certeza? Gente, apresenta agora o seu dízimo". Esse movimento faz com que o tom que poderia ser considerado como o de uma conferência (os sermões religiosos têm essa característica) acabe assemelhando-se mais a um diálogo entre pessoas afins (com afinidades); a cenografia construída é a de uma conversa franca entre amigos que desfrutam de certa intimidade. $O$ ethos mostrado é o de um homem comum, simples, do povo. Ratifica-se isso pela expressão corporal e gesticulação, Valdemiro acena ao público e manda beijos enquanto prega; sorri e fala palavras agradáveis, demonstrando afeto, como se observa em um determinado momento, quando diz, com tom afável, em relação a uma criança: "a bebezinha". O ethos de um homem simples também é produzido a partir da vestimenta do Apóstolo, que sugere um meio termo entre o formal e informal. Veste-se com camisa social de mangas longas e gravata, pois assim parece ser a obrigação de um orador que ministra a Palavra de Deus, mas opta por não utilizar terno e as mangas da camisa são dobradas até o cotovelo.

Santiago apresenta um tom que se poderia designar como mais “direto”, ou seja, há a percepção de que ele fala aquilo que pensa, sem rodeios. Observa-se isso neste trecho: “Cortou a artéria, né? Já era drogado há muitos anos, hoje é uma família abençoada”. O pastor se expressa oralmente sem formalidades, contribuindo para a construção do ethos de 
homem simples e até mesmo inculto, que se assemelharia, estereotipicamente, às pessoas mais comuns do povo. Ainda, ele faz uso da linguagem em seu registro coloquial, como se percebe nas formas reduzidas "cê" e "né” em: "Cê tem certeza?" e "Cortou a artéria, né?". Tudo isso também contribui para configuração de uma relação de simpatia e carisma com seu público.

Maingueneau (2008a), ao postular a hipótese do primado do interdiscurso e a distinção entre direito e avesso, argumenta que o interdiscurso não é, necessariamente, algo visível no texto, o Outro "não é nem um fragmento localizável, uma citação, nem uma entidade externa; não é necessário que ele seja localizável por alguma ruptura visível da compacidade do discurso" (MAINGUENEAU, 2008a, p. 37). No momento em que Valdemiro enuncia "são 5 mil igrejas, igrejas no Brasil e é a Igreja que mais cresce no mundo", não precisa que se cite quais as outras igrejas e com quem se quer fazer contraponto, pois nesse momento ele retoma o Outro (outras Igrejas, mais notadamente aquela que briga pelo mesmo lugar, a IURD). Ele menciona que batizou japonês e índio, como que em uma referência a estar em todos os lugares; e também fazendo um simulacro do Outro (não especificado) que seria "elitista”, e a IMPD seria mais abrangente e democrática. Sendo importante a conjuntura sócio-histórica na qual o discurso foi produzido, consideramos importante contextualizar que no ano em que essa pregação foi feita (e publicada), a Igreja Mundial do Poder de Deus estava no auge. Havia, pelo censo 2010, sido classificada como a Igreja que mais crescia; e um Projeto de Lei $(\mathrm{PL})^{8}$ foi criado (e aprovado) na Assembleia Legislativa de São Paulo (ALSP), o qual instituía o Dia da Igreja Mundial do Poder de Deus, dia 20 de março.

\section{CONSIDERAÇÕES FINAIS}

Colocando em um mesmo espaço discursivo a IURD e a IMPD, igrejas neopentecostais fortemente influentes na sociedade atual e inseridas nas mais diversas mídias, este trabalho objetivou analisá-las a partir da Análise de Discurso em um diálogo com a Argumentação no Discurso, pois consideramos que o discurso religioso é de visada

\footnotetext{
8 Projeto de Lei ${ }^{\circ}$ 506/2015 institui o Dia da Igreja Mundial do Poder de Deus. Disponível em https://www.al.sp.gov.br/noticia/?id=367260 . Acesso em 20 de maio de 2021.
} 
argumentativa, cujo objetivo principal é de persuadir seu auditório, nesse caso específico, a ser dizimista "fiel".

Por serem duas igrejas neopentecostais, a teologia da prosperidade é o que, de certa forma, norteia os discursos produzidos nelas e a leitura da Bíblia é sempre realizada de forma "moldada" aos interesses dessa teologia; a Bíblia é, de certa maneira, "traduzida" a serviço da teologia da prosperidade. Por isso, é preponderante um movimento discursivo que coloca a prosperidade financeira como marca da visibilidade de Deus na vida do homem. A relação estabelecida em que Deus é o passivo (responsável por fazer as vontades do fiel) é muito patente nas duas denominações. Dessa forma, foram encontrados, de maneira recorrente, enunciados constituídos a partir do "colocar Deus em prova” nas duas Igrejas. A relação estabelecida entre Deus e o homem simula uma troca "comercial": o fiel dá a Deus (em forma de dízimo ao pastor) e Ele devolve ao fiel.

$\mathrm{Na}$ análise, foi possível perceber um contraste entre formações discursivas, em especial, a partir de uma oposição constitutiva entre fé inteligente e fé irracional/emocional. Edir Macedo entende a IURD como uma igreja que se apoia em uma fé mais inteligente, mais ligada a uma suposta origem bíblica, mais próxima a Deus. Ele coloca os posicionamentos contrários aos seus como provenientes de uma "fé irracional". Por outro lado, na análise, foi possível compreender a IMPD como ligada a uma possível fé emocional, através de solicitações, por parte de Valdemiro Santiago, para que seus seguidores fizessem "dízimos em dobro", que, pela sua relação não muito definida com o um efeito prático posterior, tornam-se passíveis de relação com uma certa noção de irracionalidade.

A IURD, que se coloca como uma igreja mais "racional”, realiza um simulacro acerca da IMPD, traduzindo-a como uma igreja que se estabelece a partir de uma fé irracional. A IMPD reivindica esse sema, lendo-se não como irracional, mas sim "emocional”, que age com uma relação íntima com o sobrenatural. Por outro lado, a IMPD faz um simulacro do seu Outro como constituído por posicionamentos menos "democráticos". A IURD não assume essa "tradução" e, em vez disso, representa a si mesma como uma igreja mais próxima aos textos “originais”, portanto, mais próxima a Deus; e, por isso, com uma linguagem menos democrática, ou seja, mais difícil. Esses simulacros são resultado da constante concorrência estabelecida pelas duas denominações para ocupar o mesmo espaço social. 
A cenografia instaurada no discurso do bispo Edir Macedo remete a uma aula, na qual o aluno é considerado desprovido de conhecimentos e o professor é colocado como ser detentor de sabedoria, responsável pelos ensinamentos; o tom professoral foi preponderante na análise. Já a cenografia dos sermões dirigidos pelo apóstolo Valdemiro Santiago aproxima-se de uma conversa franca entre amigos, outras vezes, uma conversa entre pai e filhos/as - sempre com tom mais informal -, falando, aparentemente, "tudo" que vem em sua mente, sem pudor, "sem papas na língua".

\section{REFERÊNCIAS BIBLIOGRÁFICAS}

AMOSSY, Ruth. A argumentação no discurso. Tradução de Ângela Corrêa. São Paulo: Contexto, 2020.

AMOSSY, Ruth. Argumentação e Análise do Discurso: perspectivas teóricas e recortes disciplinares. Tradução de Eduardo Lopes Piris e Moisés Olímpio Ferreira. EID\&A: Revista eletrônica de estudos integrados em discurso e argumentação, n. I, p. I29-I44, nov. 201 I.

MAINGUENEAU, Dominique. Cenas da Enunciação. Organização de Sírio Possenti. São Paulo: Parábola Editorial, 20o8b.

MAINGUENEAU, Dominique. Gênese dos discursos. Tradução de Sírio Possenti. São Paulo: Parábola Editora, 2008a.

MAINGUENEAU, Dominique. Ethos, cenografia, incorporação. In: AMOSSY, Ruth (org.). Imagens de si no discurso. São Paulo: Contexto, 2016.

MAINGUENEAU, Dominique. Variações sobre o ethos. Tradução de Marcos Marcionilo. São Paulo: Parábola Editora, 2020.

PERELMAN, Chaim; OLBRECHTS-TYTECA, Lucie. Tratado da Argumentação. A Nova Retórica. Tradução Maria Ermantina Galvão G. Pereira. São Paulo: Martins Fontes, 1996.

ROSSI. Luiz. A Bíblia reinterpretada pela teologia da prosperidade. Vida Pastoral, ano 56, número 303. Disponível em: https://www.vidapastoral.com.br/artigos/temas-teologicos/abiblia-reinterpretada-pela-teologia-da-prosperidade/. Acesso em: o6 de junho 2021. 